\title{
The Dichotomy in between Ecocentrism \& Anthropocentrism: An Ecocritical Rendering of Two Indian English Poets
}

\author{
Goutam Karmakar (Corresponding author) \\ Department of Humanities and Social Sciences, National Institute of Technology Durgapur, West Bengal, India \\ E-mail: goutamkrmkr@gmail.com \\ Shri Krishan Rai \\ Department of Humanities and Social Sciences, National Institute of Technology Durgapur, West Bengal, India \\ E-mail: srikrishanrai4@gmail.com \\ Sanjukta Banerjee \\ Department of Humanities and Social Sciences, National Institute of Technology Durgapur, West Bengal, India \\ E-mail: sanjukta.dgp@gmail.com
}

Received: 18-10-2016

Published: 01-05-2017
Accepted: 15-12-2016

doi:10.7575/aiac.ijalel.v.6n.3p.15
Advance Access Published: March 2017

URL: http://dx.doi.org/10.7575/aiac.ijalel.v.6n.3p.15

\begin{abstract}
One of the plebeian environmental moral dilemmas that are noticed in third world nations are the dialectical assimilation in between anthropocentrism and ecocentrism. Owing to some devout and semipolitical prejudices some people are taking the whip hand over nature snubbing the nature, flora and fauna. But concurrently some of the great unwashed gestate in nature centered ecological system and yielding values to all non-human entities unheeding of their usefulness to human civilization. In the third world Asian countries this situation is even more abominable and eminent eco-socialists assay to exhibit this delineated envision in various ways for it becomes necessitate for them. While it is in the case of literary eminent some Indian English poets conjure up their apotheosis and cerebration through their penned composition. Poets from India on one hand depict the anthropocentric attitude of their native people and simultaneously they assume ecocentric attitude. Exalted bookmen like Keki N.Daruwalla and Shiv K.Kumar evince the world with its acculturation, sights and sounds, predilection, disillusionment, bewilderment and discombobulation ensuing from modern way of living and mentation. So from this vantage point their eco-poems arbitrate in between anthropocentrism and ecocentrism. A construe brooding of some of their oeuvre excogitate light on environmental awareness along with the enactment of human and non-human relation which is often laissez faire and patriarchal. Concurrently their perdurable compositions splay socio-ecologic discourse through which readers can ensnarl with the demography, urbanization, modernization and development of environmental activism. Their abiding oeuvre works like a mirror where the congenial understanding between man and nature along with the scope of verdict is contrived. Working within the peripheries of environmentalism their aeonian verse paves a way through which a solution within this third world environmentalism can be made possible.
\end{abstract}

Keywords: Anthropocentric, Nature, Ecocriticism, Ecocentrism, Deep-Ecology

\section{Introduction}

While mulling over on the mode and approach of above mentioned Indian English poets, it is comprehensibly perspicuous that these poets are writing in English in an Indian backdrop with Indian aesthesia. And naturally an Indian writing will certainly put accent on explicit indisputable Indian emplacement and also there will be an exhortation for a writer to constitute and corroborate his own identity and in order to do so he certainly conglomerates the local and global. While handling with these local and global they repose nature in a peerless position. For them nature is not a merely backdrop scenery nor it is precisely soul and spirits but also a living voice. Their eco-socialist posture let loose through their nonpareil compositions which become the document that exhibit the assorted forms of nature, milieu and man's relation with this nature which has been imparted a term 'ecocriticism' and generally few Indian English poetry postulate an ecocritical prefiguration as their writing substantiate the approximation and estimation which ecocriticism furnish. Adopting a briskly and exceedingly portentous move they not only render the anthropocentric attitude of indigenous people towards nature but also they become ecocentric to place nature in an altitudinous status.

\section{Research Objectives}

Apart from some stray articles on few Indian English poets not much formidable studies coupled with theoretical approaches have been attempted in this much hashed out critical topic. A cogitation towards nature-culture affinity is grappled as well as postulated as it is the betoken demand of the day because in this era of environmental crisis and 
global warming people have to be more cognizant and sentient of their role and intercession towards nature. So the objectives of the discourse are to synthesize and dissect nature from ecological perspective. Concurrently this study will manifest how anthropocentrism and ecocentrism are working in collaboration. Shedding light on how nature and man are reticulated to one other is necessitated because countries like India are confronting this problem because of first world notions of patent rights, free subsidy and marketing economical agreements along with trade development. Apart from evincing how nature is treated as 'Other', this discussion also shed light on how eco-socialist ascertain a means to sustain concordance with Nature in terms of Deep-Ecology as it is contended with repugnance to conserve ecological equipoise in Third world environmentalism. Simultaneously this discourse will facilitate in extending the canvas of ecopoetry and its censorious approach along with relevance in Indian English poetry. Besides this discourse secernates the congeneric threads between these two poets so as to take stock these poetic minds and how their poetic envision coupled with reality set forth the ground for environmental study along with sentience and effectuation. This apropos discussion will also expatiate a way for the impendent readers and environmental belligerents to perceive and espouse nature from assorted but yet bionomical perspective along with the techniques to employ it in third world res publica like India.

\section{Research Methodology}

Research Methodology adjudicates proposed work's space and the procedures espoused for the analysis of the study before the readers. This research methodology includes researcher's purports, data sources, techniques and tools which are employed to impart and bestow a contingent hypothesis. Actually in which itinerary the study is proceeding on can be traced through this research methodology. In light of the above mentioned this research paper assays to study selected Indian English poets in order to know which techniques, policies, procedural and structural methods are employed by the poets and how these methods induce a significant impingent on Indian Environment and nature-culture binaries in general. The other possible domains which are riveted on through this methodology are no more than environment and it also constitute an effort to commute and alter the motives of the people while doing by with the nature. In view with that research methodology is bifurcated in videlicet succeeding points:

\section{A. Hypothesis and Study Area}

The methodology of this discourse is comprised with the procedures of research along with the problems that third world countries are confronting in connate with nature and also data is incumbent on to dissect for the upshot of this discourse. Initially ecocriticism is delimitated in literary paradigm in a punctilious way where nature and literature and its complexions are evinced. Actually this research is analytical and theory oriented along with exploratory in nature. Braced with human beings' attitude towards nature which is anthropocentric in general, this study concurrently pores on ecocentric demeanor of selected ones and this ecocentric attitude should be intromitted ubiquitously rather than being Eco-Marxist by nature. Both preceding terms are concisely hashed out along with the context. Works of the above mentioned poets' ponder over censoriously with an appraising eye to corroborate this study. An attempt to colligate the predate discussion with Deep-Ecology and third world environmentalism is also assayed. In a nutshell Keki N.Daruwaala and Shiv K.Kumar are purposively furled to testify third world environment problems.

\section{B. Data collection and analysis}

Indian English novels are dissected often from ecocritical perspective but Indian English poetry is barely probed. The present study is executed in a corporately configured way where motley assorted papers on ecocriticism penned by luminary authors are mulled over to cater a brief definition of ecocriticism for the commencement of this discourse. After that annexed points likely anthropocentrism and ecocentrism are taken apart to induce the discourse more perspicuous and ratiocinative. The research is chiefly footed on primary database where all the books of the two mentioned poets are illatively insinuated from ecocritical perspective. The secondary databases are furnished from books and journals and for prefigurative adumbration all the primary data are reticulated with secondary databases to lay down points formalize and to consecratory yield interoperable illustration of theoretical standpoint.

\section{Defining Ecocriticism: A Briefing in a Literary Paradigm}

Broadly speaking literary criticism hash out the inter-relation between the texts, writers and the world and this world is consociated with the society and the whole social domain. Hence ecocriticism in general apprehend the entire world and the ecosphere like a theory revolve around with earth and the apparitional, ethnic and natural phenomena of the ecology. It contends with the biological facet of the earth and cultural vista of literature. Pramod K. Nayar avers in this connection, "Ecocritism is a critical mode that looks at the representation of nature and landscape in cultural texts, paying particular attention to attitudes towards 'nature' and the rhetoric employed when speaking about it. It aligns itself with ecological activism and social theory with the assumption that the rhetoric of cultural texts reflects and informs material practices towards the environment, while seeking to increase awareness about it and linking itself (and literary texts) with other ecological sciences and approaches." (Nayar, 242). 
In reality historical approaches are incurred in the annals of literature and forthwith geography is consorted with it. In order to deconstruct some cultural text, overtures are come along with the assistance of nature and social arena. Approaches are also postulated with the ethical and aesthetic dilemmas ensuing from environmental crisis. Therein literature and language transpose ethos and values with recondite ecological perceptivity. Soaring literary persona therein post-modern macrocosm becomes more eco-sentient and consecrate emphasis not only on the demolition being done to nature for bourgeois and mercenary purport but also on the bilateral alliance between nature and humanity. As a result umpteen green concepts egress and sooner this approach coupled with relation get hold of human culture and becomes an encompassing panoptic genre with many ramifications like environmental literary criticism, eco-poetics and green culture studies. Glen love aptly remarks on this approach which put vehemence on the "inter connections between the material world and human culture, specially the cultural artifacts language and literature." (Love, 196) In his illustrious essay 'Ecocriticism: What is it good for?' Robert Kern avers, "What ecocriticism calls for, then, is a fundamental shift from one context of reading to another-more specially, a movement from the human to the environmental, or at least from the exclusively human to the biocentric or ecocentric, which is to say a humanism (since we cannot evade our human status or identity) informed by an awareness of the more-than - human." (Branch and Slovic, 267). Reckoning the nascence of this term it can be mentioned that in 1978 this word came to the world with William Rueckert. In his 'Literature and Ecology: An Experiment in Ecocriticism' he says that ecocriticism entailed "application of ecology and ecological concepts to the study of literature" (Glotfelty and Fromm xx). So from the preceding discussion an estimation regarding ecocriticism can be imprinted.

\section{Two Stand-points: Environmental Ethics}

Hence the term Ecocriticism delineates two cardinal discursive studies. One is on human being and another is on Nature. This righteous affinity between Nature and human being resuscitate as Environmental ethics. It is the human beings who are exclusively colligated with Nature and his part is under interrogation since two value system come into being. One is human pored nature study or anthropocentrism and another is nature riveted system of values or ecocentrism. Both these two phases are the ways through which the propagation of ethics to nature can be construed. It employs in two crease inclined ways like moral conceive of intrinsic value of nature and human's conceptualization towards the intervention of human on nature. Let's hash out how these two personas Shiv K.Kumar and Keki N.Daruwalla fend for nature and concurrently stick out for humans by poke into their culture in order to stimulate their sentient towards Nature.

\section{A) Ecocriticism and the Anthropocentric Observation: Stands taken by Indian English Poets}

Anthropocentrism is a doctrine which reckons that human beings deem the most portentous component in the cosmos and they comport with altitudinous righteous values and only he relish his fame and bask in his glory in the society. Hence this term can be delimitated as human exceptionalism or humanocentrism. Man is upholding nature in order to derive assistance from it. Being conceived as 'other', nature is subjugated, quashed, subdued and dominated by human beings. Anthropocentrism corroboratory affirms that the germ of environmental crisis is reposed in mankind. Hyponymy over flora-fauna disseminate the subject-object distinction as half virtual truth because some non-human elements recrudesce and evolve whereas others are still in a mode of subordination. Poets like Daruwalla and Kumar assay to exhibit this in their oeuvre by grapping with ecology. What anthropocentrism weighs is also a slanted derivative persuasion recounting with values? Suffice reposes within this incertitude. Corresponding with mundane, Nature should relish its pursuance for both man and nature subsist and populate asseverate humanistic precepts and ecological maxims for both assimilating ingest intrinsic value. Daruwalla and Kumar conjure up with approximation in how both nature and human beings end-in-itself or how they conforms the norms of Kantian concept of being in itself. There in the ecological system two intrinsic values are working videlicet Intrinsic multism where many things hold life principle and constitute life stance and other is Intrinsic panism which believes that both nature and man retain intrinsic values, purposes, terminuses and land up in itself only to commence again in unprecedented contour.

Adopting a deconstructive turn these two personas conceive that there are no rigid and constant ethical and moral terminuses. What anthropocentrism assumes is that human lineaments videlicet secernment, discernment, perceptiveness, repossession, monomania, self-module faculties are accountable and amenable for his moral and ethical goals? But a few co-socialists like Kumar and Daruwalla cogitate that some humans like unhinged patients, perturb infants and changeling morons have no such sagacious perceptiveness and their distinctiveness gibe with some dehumanized natural constituent. Hence the perspective of moral object must be expatiated to concord both life and nature. It is veritably gumption to intromit anthropocentrism with Marxism where nature is repugning as an object of manipulation and defilement. Environmental degradation such as global warming, contamination, cataclysm like draught, inundation, dearth, ozone layer depletion contaminate and dissemble the world environment in a colossal way. These are the upshot of the meddling of human beings with nature. Even the extinction of scrimpiness of flora fauna is the aftermath of inconsiderate mercantile clientele transaction of human being. Besides industrialization and colonialism in third world countries stimulate the situation more abominable and deplorable. Hence Poets from Asian countries postulate this role to assign values to all embodiment of life on earth to necessitate a concordance between man and nature.

\section{B) Ecocentrism: An effort for harmonizing Nature and Humans - Green Politics of Indian English Poets}

Postulating a very epoch-making stand Indian English poets' wielding the semiotics of nature-culture binaries corroborates the norms of ecocentrism which heralds nature centered value system with an ontological stand with no distinction between human and nature. Abnegating the fact of human's superiority over nature, Daruwalla and Kumar 
locomote beyond the biosperical egalitarianism and necessitates equality between human nature. Going beyond the binaries of shallow and deep ecology they arrogate an ecumenical stand where both life centered and human centered values coalesce together asseverating the ethics of whole environmentalism. Within one term 'environmentalism', their oeuvres impart instrumental as well as intrinsic value of nature to auspicate it from the flagitious activities of human being. Sustaining the mythos of social crusades they assay to protect, rejuvenate and ameliorate concurrent stipulation of environment for the whole non-human organisms deserve commensurate grandness.

Parturient as unplumbed green ecologists, Daruwalla and Kumar exhibit their perspective against techno-centrism which facilitates human beings in controlling the environment for industrial and technological expansions are the root cause of environmental degradation. Forging within the fringe of ecology they limn landscape, water bodies, desert, grassland, forest, plains and animals for in this ecosystem human beings embedded and evolved. Subsequently evincing the anthropocentric perspective these green politicians conflate Marxism, socialism with their green oeuvre by going beyond anti-globalization. For fabricating an ecologically sustainable society these unwavering worshipper of nonviolence and grassroots democracy project their penning as specimen of eco-political pamphlets. Picking apart the autochthonic people for their bureaucratic laissez faire emplacement towards non-human, they endorse social progressivism for these vaticinators envisage nonviolent mettlesome new guild.

\title{
6. Theoritical Approaches in Practice: A Green Study of Two Indian English Poets
}

From the get-go pre-independence Indian English poets gibe to regulate modes and manners of British romantic poets. But in the posterior Indian English poetry derives maturity through experimentation, instauration, assimilation and acculturation with faux simulation. They become more evocative and redolent of their descent and nationality and Indianness is ascertained in their oeuvre as they are grappling with Indian nature, environment, rivers, birds and landscapes with exclusively enhancive posture through a bucolic caprice. Poets like Toru Dutt, G.C.Dutt, Rabindranath Tagore, R.R Shrestha, Manmohan Ghose, Sarojini Naidu of the earlier period assay their best to glamorize and befuddle the phlegmatically outlook of nature. But in the piecemeal the later modern poets became more redolent about the environment and they limn the actual stipulation of it with pragmatism. Poets like Gieve Patel, Keki N.Daruwalla, Vikram Seth, Shiv K.Kumar, Dilip Chitre, A.K.Meherotra and many others became satirical, cynical and realistic in portraying man's attitude towards these natural elements.

\section{A) Shiv K.Kumar and Postmodern Ecocentric Approach}

Born in the year 1921, Shiv K.Kumar becomes one of the brightest stars on the horizon of postmodern India with his subtlety of perception that lies at the centre of his creative thought process. From the very beginning he is in search of some truth, the core and the fundamentals that unveil illusion and generally his works becomes the path of open realism that surely transcends appearance. In his poems he always seeks to find the real and external and in case of nature, he takes a very significant approach and his poems are filled with the semiotics of nature-culture binaries. Being a postmodern poet, he questions the so called ecocritical view of 'Representation' and turns to the root of environmental crisis with dualistic paradigm in order to subvert the nature-culture binaries. In his poems he denies the on-going ecological concept of domination of nature and thus paves a new way for discussion. Anthropocentric values are the source of ecological oppression. His poems open a new horizon which shows the destructive cultural and social matrices that make environmental crisis. Actually going beyond binaries, he takes a postmodern ecocentric approach by opening the inabilities of contemporary cultural and social epistemologies and structures as power poles that is responsible for the deterioration of human communities now. As a postmodern ecocentric he not only tries to displace nature from the so-called 'Other' position but also shows how indifference of man to nature make it hostile and destructive sometimes. So he also criticizes the anthropocentric attitudes of human beings and the same time he takes ecocentric advances to make a bridge between man and nature.

Nature is reduced to nothing because of the scarcity in terms of logical and radical textualism where environmental crisis is put in question as often epistemic relativism and cultural constructivism leaves little space for nature to question the eternal anthropocentric thoughts. Kumar in his 'Talking to a Bird on my Window-Sill' makes a real distinction between human world and the natural world and the bird here is the representative voice of the natural world. He says: "You seem to chirp your way through life/never a streak of sorrow/in your beady eyes./You don't know the problems I have to face/darkness, rain, nightmares..."(WL,3). In his 'Niagara Falls' he presents nature as a supreme force that can wipe out human beings and here the water of the Niagara Falls is the representative voice. He wants to make people remind: "Now the Falls remind us that water/is more potent than rock,/more lethal than a woman's fangs." (TSTB,25) Being a poet with Indian sensibility he shows his concern for the holy river Ganga as he wants to keep intact human's holy Communion with nature and the Ganges. In his 'Cleansing Ganga', he not only shows how human pollute this holy river but also ironically suggests the human being to clean themselves from hypocrisy, orthodoxy and money minded impulses. Here he says:

\author{
"It's only when they are carried down the river of time \\ that iron sinks into their souls. \\ The waters then get sullied by ritual and dogma- \\ ashes and bones, \\ wilted floral offering to the dead, \\ ...Maybe if someone could dismantle all scaffoldings \\ along the mother river's waistline.” (Selected Poems, 73)
}


By exploring nature's oppression within anthropocentric discourse, poets like Kumar with his postmodern lenses show how nature behaves within this discourse. He shows how this techno-culture destroys every symbol of beauty to a painful sordid state and the moon is no more exception. In his 'I Shall Not Gaze at the Moon Again' he shows the moon not as the charming Cynthia but "She is some woman of ill-fame,/...her Sea of Fertility dried up./Call her not Cynthia/...but some ominous genie of the firmament." (AS,31). In 'Moongazing', he utters a cry for the moon which is physically invaded by humans as they are like ramparts doing hostile movements and the cosmic beauty is also under scrutiny of the intruders and they are there 'to find/some evidence of stolen property/from their planet where suspicion/worms into everyone's brain/like a malignant tumour." (WL,10). In his 'Felling a Tree', he projects the human being as murderers who are willing to murder trees and it becomes a ceremonial task for them. Here the poet longs for a banyan tree which is cut down and the poet cries for the tree by questioning divine justice for the tree because he says, "justicers up in heaven,/care only for humans?/Where will each part of this tree end up, I asked myself./No logwood fire for me hereafter,/nor would I touch the wooden frame/of my window, lest my fingers/get stained with blood." (Where have the Dead Gone?,84). Kumar always believes in natural harmony and spontaneity. But this harmony is affected by the human activities and in his 'An Unseasonal Rain in Nagpur', he shows his unhappiness as nature is behaving in an unusual way due to the activities of the nuclear bombs as he says "I don't want a season's natural rhythms tampered with/even by nuclear clouds/so used I am to fire and brimstone." (WL, 57). No matter the age is advancing with great technologies but man is getting uprooted from nature's love, peace and serenity as this technoculture can't bring feelings of joy or sorrow with its own as it is depending upon feeding which may be malicious and scandalous. As in his 'The Computer', he described this marvel of science as "black kitten, which leapt/through a broken glass-pane/onto my chest." (WL,55)

Kumar shows nature as a complex phenomenon and his poems show complex binaries of disorder and order, multivocal and polysemic with conflicting viewpoints along with instability and evolution. So naturally diversity is shown there and his poems explore the complex relation between nature and culture in order to reconstruct and redefine nature in a decontextualized discourse. He steps forward to the postmodern ecocentric approach when he questions on all hierchial systems which put emphasis on the exploitation and domination of nature. In order to create a constructive relation between nature and culture he places nature in the center of his poems. Nature is displaced from 'Other' to some entity sometimes more powerful than humans and culture. Disregarding the human authority he celebrates the nature in order to create an aesthetic beauty in human beings which may transform them from anthropocentric to ecocentric nature and only then the concept of Deep-Ecology can work. He is particularly fascinated with sun as it is the prime symbol of life. So beauties of sunrise, noontime and sunset are presented in vivid picturesque way. In his 'Genesis', he describes the sunrise with sensuous images like "the infant orange sunrise/not yet matured into.../And out of the frothy ripples/of this nebulous sea..." (AS,16) Kumar sometimes like metaphysical poets takes the cosmic objects like sun as a spherical body, an instrument of power which deprives each objects of its shadow. Actually the poet is here to show natural objects as supreme force which can take control of everyone. This notion is reflected in his 'Noontime: Summer' where he asserts the brutal energy of the sun which recants all commitments with own impulses and thus he questions:

$$
\begin{aligned}
& \text { "Why should the sun be the force } \\
& \text { behind leaf, fruit or flower } \\
& \text { and also be an assassin?" (WL,68). }
\end{aligned}
$$

Being a high priest of postmodernism Kumar always de-centers the truth to question the age old ideologies and in his 'Mission Beach' he also questions on human authority as man is here shown in a mode of inner frustration and seeks to find solace in nature. Here the poet tries to counterbalance man's inner depression with the beauty under the water in vivid Shelleyan way with apt imagery with the soldier craps: "On the beach the soldier crabs/They gasp on the brown sands./Somewhere/below the glasshouse of water/polyps and fronds of coral clusters/exchange fish-whispering/in bubble words/that have no bellies." (CITS, 3). In his 'Fisherman' he shows how the fishermen are capturing the sea's secret possessions, the fishers for selling. Here the poet shows how nature is protesting against man's commercial attitude towards natural treasures in a symbolic way through the sea breakers and this poem also merges both anthropocentric and ecocentric aspects of human beings and the poet and more surprisingly the irony lies here as both are human and still possessing different attitude. The struggle of the sea to protect her treasures really puts question on Marxist approach of humans: "But the sea convulses/to watch her secrets/laid out for marketing/on the sands/often she sends out/in hot pursuit/her surf-turbaned breakers/to recapture/some of her lost pride." (CITS,16) Not only the sea but also animals, birds and even the mountain get equal attention from Kumar as all these have intrinsic values which is denied by the humans. But it is the time to make people aware about their existence and importance. In his 'The Himalayas', he celebrates the love and life-force as seen in this mountain range as the poet says: "It's not on top of the Everest/that truth resides/but beneath its roots/...Love, not the sun, is real/sustenance to seed, fruit, flower/and the soul/...but it celebrates life, not doom." (TSTB, 34) Poems like 'The Squirrel', 'A Monkey Show', and 'King Cobra at the Zoo' show his concern over animals. Nature's plea for liberation from the bondage of human authority is found expression in 'The Monkey Show' where the monkeys are roped together to hop in order to entertain people and thus collecting coins from them for their master but they are longing for freedom. A purity of freedom and primitive man's unencumbered passion is reflected here as nature is not for bondage but for liberation. Here the monkeys' eyes are wandering: 


$$
\begin{aligned}
& \text { "off to a distant vision } \\
& \text { of an evergreen forest of fruit and flower. } \\
& \text { Oh, to leap from one thought-bought to another } \\
& \text { across vast spaces of freedom." (WL,28) }
\end{aligned}
$$

Being a postmodern poet Kumar always tries to give importance on harmony which is very core of existence and always in praise of nature and its surroundings. As in 'Niagara Falls' he shows the destructive forces of nature as 'Now the Falls remind us that water/is more potent than rock,/more lethal than a woman's fangs.” (TSTB,25) But the balance is also created when the poet shows the lake water in 'Lake Gandipet, Hyderabad' where the lake water is not as fierce as Niagara but rather in placid and contemplated state as 'the lake napping/like a crocodile on the sand/It's tranquil.../The lake's placid surface is a canopy/under which same sage is meditating/on the life around." (TSTB,37) Harmony is more prominent when the poet juxtaposes the natural world with the human world suffered by harsh realities and an existential cry is heard when the poet assets: "A rude branch's brush against my forehead/prods me into realizing that fantasies/are only for the moon and stars,/not for the mortals who are prone to chills and fevers."(WL,64). Again the supremacy of nature is presented as it is not possible for the human to enjoy natural bliss as they are unworthy of appreciating the beauties in nature. Kumar is not only an ecocritic but a great symbolist and this is shown when he projects a tree's physiology of a tree which wishes to be liberated from human bondage and he shows how a tree is trying to make a balance in this world: "they are only balancing themselves/around some invisible/core." (CITS, 39) Being an ecocritic he tries to make people aware about the innate worth of all natural elements as all have life-force and the human beings should protect these in order to avert danger. In his 'Trees', his postmodern ecocentric attitude reaches to summit where a tree is shown as:

$$
\begin{aligned}
& \text { "forge a cover/ } \\
& \text { for the sky and the earth to mate } \\
& \text { on the horizon's sundown bed } \\
& \text {...Plant them each three feet apart } \\
& \text { to ensure ripe wisdom." (WL,38) }
\end{aligned}
$$

\section{B) Keki N.Daruwalla and the Ecological Interplay of Binaries}

What stimulates Keki N.Daruwalla a lofty poetic persona with ever-growing development of poetic mind is his aesthesia which is incessantly policed by the transcendence and immanence of nature and his engagement in naturalism patently postulates man's status in relation to the various aspects of nature. A unsounded discernment to some of his penned compositions projects that Daruwalla's poetic journey is a womb-to-tomb pursuance where the poet uses his harnessed aggression and in later his mellowed temperament with highly sedate realism in order to identify himself and in doing so his poems exhibit a constant interplay of binaries between nature and culture and in between decentralization of human authority and revaluing and relocating the essence of nature. He uses his culture as a metaphor for nature and broadly speaking his poems postulate relevance of an ecocritical approach. Disdaining the idea of portraying nature not only for locale representation, he swans more importance to non-human setting as a presence that states that human history is delineated from the natural history. He does not only gestate upon the human interest and generally his nature poems impart with the details of human accountability to environmental issues and the study of nature-human relation is inherent in his texts.

This is an irrefutable fact that Daruwalla's vision of the future is not a pollyannaish one but rather he promulgates the advent of approaching doom. Man in course of journey becomes so anthropocentric that he is caught among the natural forces. Assaying to fix his identity, he corroborates the aesthetic existence in nature and in doing so he is in league with the sea and dusk but the human only witness what the poet says in his 'I Walk The Sands, No Sirens Sing': "My destiny/to merely sizzle, fret and fail./Lover's silence haunts; the sea/and I make moan." (CL,10). The poet depicts how human being in a certain point of time pines for the company of nature as it is only nature which can provide him comfort in this materialistic world. So human decentralization is presented here which at the same time projects value on natural resources. This interplay of binaries is presented in his 'Goddess I Am Lonely Now' where the man cries: "Goddess I am lonely now,/The Pleiades and the moon have set,/I sleep alone./Love's desertions, they are swift,/as star clusters incline and shift.../I drift alone.” (CL,10). Actually the poet shows the post-independence India as a landscape of meaninglessness where drought, corruption, poverty and passion proceed in a same way and in his 'Collage II' he says: "Then why should I tread the kafka beat/or the Waste Land/when Mother, you are neat at hand/one vast, sprawling defeat?" (CL,70). Being a poet of realism he has sharply presented the society and human world where hunger, evergrowing population, growing sense of loss and growing apprehension at arms race and nuclear proliferation are visible. In his 'Angst' he shows how technological advancement create environmental degradation as forests, cliffs are going to face this impending danger: "Death-light that falls/like a rain of radioactive spikes/Death-light that falls/through holes in the ozone belt./Cows grazing on meadows of bitumen/ A bulldozer that shovels/children over a cliff./...the forests of the earth,/turning to deserts;" (WP,19). Interplay of binaries is present in his 'Easy and Difficult Animals' where he places the human worlds and natural worlds side by side in order to show that being a difficult animal he is not at all 
oblivious of easy animals as they are given ample importance over difficult animals "you lumped together as 'easy animals'/And pitched against this menagerie/one solitary cry/the one 'difficult animal'/that was I." (CL,58)

Coupled with metaphor and symbolic overtone Daruwalla's poetry always shows man in a crisis moment as his very existence is put under question and at the same time nature and its importance is also shown in a different way. This nature-human binaries is present in his 'Calender, starting with June' where people and all natural surroundings are affected for the lack of rain. Here he shows how human activities make nature hostile and make an ecological imbalance as in the month of rain, heat and hot wind persist and every other creature is in fear for an impending danger and draught as "The land is an earthen dish,/empty as always.../The coppersmith bird shrieks insistent/that death is round the corner." (WP,23). Man is getting benefited from nature and depend on nature so much that when nature becomes hostile then he finds no other way out to find a way of living. In his 'The Wringing of Hands' he shows how drought has hit the coastal area and due to this natural calamity people are living a miserable and painful life and at the same time it is the rich upper-class and politicians and corrupt officials are exploiting this situation. So man never takes upper hand over nature and it is the man's activity which makes this drought possible and now even the sea becomes so hostile that it does not allow the fishermen to take it's treasure and now "He walked over land dry enough to set fire to./Hard enough to crucify a God on./Cracks wide enough to swallow a million Sitas./...A day, a night, another day and still/no fish, and then the sweats broke/His heart heaved and strained like a hooked fish/And stumbled into a murmurlers quiet." (WP.35-36). Daruwalla is cognizant and evocative about the technological advancement of his age and this techno-culture sometimes imparts no hope for mankind because man is now destroying nature in order to make more profit. This eco-culture and techno-culture binaries often ascertain satirical expression in his 'Einstein Explains to God the End of the World' where he is pleading before God and says "Don't tear your hair, Lord./If the angels were to see you doing this/there would be a commotion./This is the age of science./We have no place for emotion." (WP,64).

An originative and constructive interplay of the ikon and the statement is exhibited in his 'landscapes' published in 1987. Contemporary time and its relation with nature are delineated along with the meaningless fragmented disillusioned landscapes of India. Nature-culture binaries are present here and he extends it from ancient kingdom of Kalinga to modern metropolitan cities. In his 'Mandwa' the death of the baby-whale reminds Coleridge's mariner's killing of 'Albatross'. The baby-whale is the symbol of purity and innocence and its killing yields humans motive of exploration unknowingly knowing the dilemma of 'life in death' and the last lines are showing man's callousness where "no one remembers/seeing a myth die/amidst a shoal of dancing bubblers." (CL,194). Human beings will face impending danger as they are doing harm to nature and the consequence is yet to come. So the poet's mind crosses with anxiety and impending loss and he says it in 'Lambing' where he says "I lie still, knowing pain is next door/...We would die of bloat, he said,/if we fed on clovers./...the lamb within me has turned urgent/as it twists and strains against my side/and turns as I turn against the straw rick." (CL,198-199) A continuous interplay of ethical orientation along with inhuman human activities and adverse effects on nature and his poems carry the message of a dying generation and a generation inviting calamities. Atrocities on nature is presented by him in a satiric way where there is an interplay of his pessimistic voice and also a gateway for concerning the future generation about what to do and what not. In his 'The Fall of Mohenjo Daro' he shows that death of a civilization as "There was no escape, the high treble/of their neighing paralysed us.../The years will not go round for us." (CL,224). In his 'Boat-ride along the Ganga' the interplay of two cultures are shown as the city Benaras and its people are depicted in a particular money minded corrupted souls and on the side the Ganga is presented as mother, daughter and moreover a sacred source for those corrupted people. The last few lines of the poem aptly illustrate this interplay of two binaries:

"Dante would have been confused here.

Where would he place this city

In Paradise or Purgatory, or lower down

Where fires smoulder beyond the reach of pity?

The concept of the goddess baffles you-

Ganga as mother,daughter,bribe.

What plane of destiny have I arrived at

where corpse-fires and cooking-fires

burn side by side?" (CL,98)

\section{From Margin to Centre: Indian English Poets and the Journey towards Deep-Ecology in Third World Environmentalism}

Apart from espousing ecological and ecoaesthetical perspectives towards nature, these two personas concurrently spill the working of Deep-Ecology where there is a scarceness of land for the downtrodden calamitous people for they assay to constitute a way where auspices of wilderness is still contingent and feasible. In compliance with an ecocritical approach based on the integrative centripetal precepts of all stellar environmental facets rife in nonclassical dimension, they irremissibly want to stimulate an equipoise between human and nature while grappling with environmental upshots in a third world developing country like India. Their articulation become ethics, a common encrypt of solution for an ethical environmental future and this should be the grassroots for the great unwashed upkeeping in third macrocosm. 
Development is a gordian process in countries like India where the demolition of nature is a concurrent happenings ensuing from Western ideologies of development. Nature becomes the rootage of furnishing unprocessed stuff and in his book 'Environmentalism: A Global History', Ramachandra Guha avers incisively the same that "Nature becomes a source of cheap raw material as well as a sink for dumping the unwanted residues of economic growth". (Guha, 4). Like Guha, these two rarified mortals also pull in the rudimentary truth and reality behind the third world environmentalism. In order to obviate environmental crisis, the most copernican step that must be taken is the conservation of land but aggravated paucity of lands and funds induce it more convoluted. They depict how man out of their dire need and immiseration exploit nature begrudgingly from materialistic standpoint and this happens because of anisometric distribution of wealth, resources and opportunity among human beings. Evincing these detonations these two adept mavens strive to remold the Deep-Ecological excogitations in their oeuvres.

Modern Environmental consciousness is a response to the increasing actualization of terrestrial environmental demolition and abjection and this cognizance egressing from western middleclass origin does not creditable and exemplary with third world countries like India where the oppugn of equity persists. Survival question unremittingly prevail as one of the quintessential lineament of India whereas umpteen environmental justice movements purport to protect nature for the impecunious and hapless segment. Liberal ecologism is gestated and this dissent first world environmentalism from the third one. Here lofty Indian English poetic personas postulate prodigious stand to swan modification in few doable arenas which emplace them in between environmentalism of the destitute and impoverished and deep-ecogical perspective. Getting hold of the kernel precepts of deep-ecology, they consecrate towering esteem to the living environment by conjuring up their veracious voice for the natural organism's right to live and thrive. Ecologically Marxist precepts with inequality of all incumbent things regarding oppugn of dissemination persist as baffling and elusive. Realizing these problems poets assert equal intrinsic values to nonhuman and human life with the elucidation and usefulness of anthropoid values to human purposes. Realizing the necessitation of the wretched to utilize nature for survival, they send words to the great unwashed for nourishment of the multifariousness of nature's cornucopia and mellowness. Poets like Shiv K.Kumar protrudes nature as a background for every human deed for its cornucopia and multifariousness append plethora to human's life. Grappling with the interrelation between human and nature in third world is reckoned as a convoluted process for the macrocosm of organism is not fissiparous as it animadvert on the beingness of others and sometimes human encumbrance is inducing menace and scourge unremarkably to human and nature. While anthropocentric earthborn compels track down nature, these two soaring ecosocialists assay to nullify it. Taking a more holistic view these poets give life to the nature and also try to create a modern human society keeping in mind the obstacles they are facing. Eminent hulks like Keki. N. Daruwalla lays down his penned compositions a vehicle through which environmental justice motility bob up among the masses. This movement is constitutional and substantive for Indian as it postulates consecration of humans along with mother Earth's sacrosanctness and concurrently it does not accord with ecological demolition. Daruwalla places nature in ossification with God to limn whiteness and sanctitude. What Mira Behn avers regarding Mother Earth befits perfectly well in Daruwalla's poetry: "The tragedy today is that educated and moneyed classes are together out of touch with the vital fundamentals of existence-our Mother Earth, and the animal and vegetable population which she sustains? This world of Nature's planning is ruthlessly plundered...We have got to study Nature's balance, and develop our lives within her laws, if we are to survive as a physically healthy and morally decent species." (Guha,67). The concurrent precepts pertain to humungous change showing the present human-nature relation of exploitation and simultaneously their perdurable lines endorse those basic ideologies, economic and technological conditions which are susceptible to dislodge for explicate an amended excogitation of human-nature intercession

\section{Conclusion}

These two poetic personas are endued prognosticator and retain the capacity to foresee the future as their pieces previse the people that would arise in prospective time and this makes them truly poets of lofty caliber. With their highly simple diction free from literary decorativeness and artificiality, they verbalize an austere intellection reckoning ecology in their penned compositions. Their patently decorated works with great chasteness make readers perceive about the ongoing relation between mankind and environment and generally their documentations become the extant manuscripts through which one can behold the condition of nature and environment. In a very mooted and grossing tactical way they array the burning issues of the day with tortuous transition of ecological equilibrium. Gregarious natural tempestuousness becomes the topic for there repose the need to divulge the nature which is shackled by modern lifestyle, gentry, philistinism and technological expansion. Besides these they harbor a chiseled purpose behind penning those volumes. On one hand these compositions are connoting concern for environmental issues and demands attention of the world by portraying man's actual attitude towards nature and contrastively those are the articulation of dissent against the insensate attitude of humans towards environment. Masses must have to be level-headed and they have to conserve the nature which is not sustainable. This community and planet involve around the nature which is actually the spirit and individuality of them. Despite the binary resistance of nature and culture, these poems testify this acknowledged verity.

But all these reckon on the man's dynamic and propelling attitude as these documents are penned in such an environment where exploitation and preservation both demand their way. At the lineal instant their works may seem to be a dilatory and baffling transitional objects but it is also indispensable to conflagrate a concern in the current social and economic structures. Their works may enkindle a sensation among ongoing researchers to evolve ongoing economic development and moderation on usance. It may not be a perpetual consummate solution but through these documents a glimpse of better future with amended social and economic pattern can be envisaged. And if the majorities 
commence to cerebrate in this way and if the individual rivet on basic needs and recycling of wastage along with organic and sustainable disjunctive power source then progress can be made possible without much change in first world consciousness.

\section{References}

Daruwalla, K. N. (1980). Winter Poems. New Delhi: Allied Publishers.

Daruwalla, K. N. (2006). Collected Poems 1970-2005. New Delhi: Penguin Books.

Kumar, Sh. K. (1970). Articulate Silences. Calcutta: Writers Workshop.

Kumar, Sh. K. (1974). Cobwebs in the Sun. New Delhi: Tata McGraw-Hill.

Kumar, Sh. K. (1976). Subterfuges. Delhi: Oxford University Press.

Kumar, Sh. K. (1998). Woolgathering. Hyderabad: Orient Longman Ltd.

Kumar, Sh. K. (2001). Thus Spake the Buddha. New Delhi: UBS Publishers’ Distribution Pvt. Ltd.

Kumar, Sh. K. (2011). Which of my Selves Do you wish to Speak to? Selected Poems. New Delhi: Penguin Group.

Kumar, Sh. K. (2014). Where have the Dead Gone? \& Other Poems. New Delhi: Authorpress.

Anderson, Lorraine, Scott Slovaic, and John P O’Grady. (1999). Literature and the Environment: A Reader on Nature and Culture. New York: Longman.

Bennet, Michael, and David W Teague. (1999). The Nature of Cities: Ecocriticism and Urban Environments. Tucson: University of Arizona Press.

Murphy, Patric D. (2010). Ecocritical Explotions in Literary and Cultural Studies. Lanham: Lexington Books, pp. $45-$ 67.

Morton, T. (2007). Ecology without Nature: Rethinking Environmental Aesthetics. Cambridge: Harvard University Press, pp. 121-145.

Kerride, R., and Neil, S. (1998). Writing the Environment: Ecocriticism and Literature. Zed Books.

Elder, John. (1996). Imagining the Earth: Poetry and the Vision of Nature. University of Georgia Press, pp. 69-91.

Clark, T. (2011). The Cambridge Introduction to Literature and the Environment. New York: Cambridge University Press.

Armbruster, K., and Kathleen R.W. (2001) Beyond Nature Writing: Expanding the Boundaries of Ecocriticism. Charlottesville: University Press of Virginia.

Love, G. A. (2003). Practical Ecocriticism: Literature, Biology, and the Environment. Virginia: University Press of Virginia. Print, Pp. 175-197.

Garrad, G. (2004). Ecocriticism. London and New Work: Routledge.

Branch, P.M., and Scott, S. (2003). The ISLE Reader: Ecocriticism.1993-2003. Athens and London: University of Georgia Press, pp. 260-270.

Glotfelty, Ch., and Harold, F. (1996). The Ecocriticism Reader: Landmarks in Literary Ecology. Athens and London: University of Georgia Press.

Nayar, P. K. (2013). Contemporary Literary and Cultural Theory: From Structuralism to Ecocriticism. New Delhi: Dorling Kindersley Pvt. Ltd, licences of Pearson, pp. 241-253.

Fenn, V. (2015). Roots of Ecocriticism: An Exploration of the history of Ecocriticism, A Literary Theory of the Postmodern World. Veda's Journal of English Language and Literature, 2(2), pp. 114-119. Web.

Sinha, R.N. (2009). The Poetry of Keki N. Daruwalla. New Delhi: B. R. Publishing Corporation

Singh, R.A. (2002). The Poetry of Keki N. Daruwalla. Jaipur: Book Enclave.

Singh, P. K. (2001). A Passage to Shiv K. Kumar (From Agony to Ecstasy). New Delhi: Sarup \& Sons.

\section{Notes}

Abbreviations are used here quite a few times while mentioning the names of the poets' works. Here the full names and abbreviated forms are mentioned- WP for Winter Poems, CP for Collected Poems 1970-2005, AS for Articulate Silences, WL for Woolgathering, TSTB for Thus Spake the Buddha \& CITS for Cobwebs in the Sun. 